\title{
How Can Service-Learning Prepare Students for the Workforce? Exploring the Potential of Positive Psychological Capital
}

\author{
Dr. L.J. McElravy \\ Dr. Gina Matkin \\ Dr. Lindsay J. Hastings
}

\begin{abstract}
Although service-learning increases several important development and learning outcomes in college students (Yorio \& Ye, 2012), it is not clear whether service-learning is better preparing these students for their future careers (Gray, Ondaatje, Fricker, \& Geschwind, 2000). To better understand the influence of service-learning on student development, an exploration of a leadership service-learning course and an important workplace attribute, Positive Psychological Capital, are theoretically explored.
\end{abstract}

\section{Introduction and Purpose}

Service-learning is an experiential pedagogical tool that enhances learning through students engaging in course content in applied community service projects and reflection activities (Madsen, 2004). The use of service-learning in leadership courses is well documented (Zimmerman-Oster \& Burkhardt, 1999), and researchers exploring the impact of service-learning have provided evidence for some of the expected benefits, including increases in learning (Strage, 2000), civic responsibility (Myers-Lipton, 1998), choosing service-related occupations (Reed, Jernstedt, Hawley, Reber, \& DuBois, 2005), and social justice (Keen \& Hall, 2009). The potential impact of service-learning in leadership coursework however is not simply limited to promoting students' civic and community engagement. Through service-learning, students are also expected to develop knowledge, skills, and dispositions to help them in their future careers (Govekar \& Rishi, 2007; Papamarcos, 2005), even if those careers are not in the government or not-for-profit sectors. For example, service-learning provides students the opportunity to engage in the community through volunteering, and the experience provides a relevant context for learning about important leadership skills, including adaptability and innovation (Govekar \& Rishi, 2007) and interpersonal and problem solving skills (Moely, McFarland, Miron, Mercer, \& Ilustre, 2002). However, the direct link of service learning to career preparedness has had mixed results (Gray, Ondaatje, Fricker, \& Geschwind, 2000). Specifically, the impact of servicelearning on self-evaluative processes, including self-efficacy and self-esteem, which are largely regarded as having a positive relationship with job satisfaction and work performance (Bono \& Judge, 2003; Stajkovic \& Luthans, 1998), are mixed (Bernacki \& Jaeger, 2008; Knapp, Fisher, \& Levesque-Bristol, 2010; Osborne, Hammerich, \& Hensley, 1998). Furthermore, a recurring criticism of service-learning research is the lack of quality research using defensible, wellestablished assessments (Bringle \& Steinberg, 2010; Moely, Mercer, Ilustre, Miron, \& McFarland, 2002; Papmarcos, 2005; Reeb, 2006). Despite the recommendations to use servicelearning, the mixed findings on self-evaluative processes (e.g. self-efficacy and self-esteem) 
demonstrates a gap in the research. Furthermore, a sound theoretical foundation is the first step to generating research that is likely to address this gap.

In an effort to build the empirical foundation for the appropriateness of service-learning in preparing leadership students for future careers, a relatively new self-evaluative construct is explored, positive psychological capital (PsyCap; Luthans, Luthans, \& Luthans, 2004). Because evidence suggests that PsyCap (Luthans, Avolio, Avey, \& Norman, 2007) has a reliable measure that demonstrates predictive validity with workplace success, this theoretical review will provide needed insight about the potential impact of service-learning on career preparedness. The purpose of this paper is to describe how students' levels of PsyCap could be impacted by a service-learning leadership course, and to provide practical applications of pedagogical strategies to promote workplace readiness development.

\section{Literature Review}

Service-Learning. Service-learning is an experiential teaching and learning pedagogy, as students are provided direct experience to link the course content to real-world situations. The reciprocity between student learning and community partner benefits provides the framework for preparing future civic responsibility. As such, considerable amount of research on servicelearning has focused on student outcomes associated with social/civic responsibility (MyersLipton, 1998), social change (Lewis, 2004), moral development (Bernacki \& Jaeger, 2008; Boss, 1994), personal value development (Markus, Howard, \& King, 1993), cognitive complexity (Osborne et al., 1998), and awareness of differences and appreciation of diversity (Einfeld \& Collins, 2008; Roodin, Brown, \& Shedlock, 2013). Furthermore, given that service-learning occurs in institutions of higher education, it is no surprise that much of the research has also established broad support for the positive impact service-learning can have on cognitive development and enhancing content knowledge (Conway, Amel, \& Gerwien, 2009; Yorio \& Ye, 2012). In contrast, very little research has explored how service learning might impact student preparedness to enter the workforce. Even when outcomes expected to be associated with preparing students for the workplace (for example the Civic Attitudes and Skills Questionnaire includes a leadership and social skills factor; Moely, Mercer, et al., 2002), the measures used to assess the constructs have not been tested for predictive validity within the workplace environment.

A recent meta-analysis conducted by Yorio and Ye (2012) analyzed 40 studies categorized into one of three learning outcomes, cognitive development, understanding social issues, and personal insight. Though the reported effect sizes were significant for each learning outcome (cognitive development, Est. $\delta=.52, \mathrm{p}<.01$; understanding social issues, $($ Est. $\delta=.34$ $\mathrm{p}<.01$; personal insight, $($ Est. $\delta=0.28, \mathrm{p}<.01)$, one caveat should be explained about these results in relation to the personal insight outcome. The meta-analyzed effect sizes were taken as absolute values even though there was evidence that the effects of service-learning with the personal insight criterion variables were both positive and negative. After reporting a decrease in self-esteem after students completed their service-learning course, Osborne and colleagues (1998) suggest that the decrease "may represent a more realistic assessment of self-worth than at 
the onset of the semester" (p. 9). Yorio and Ye (2012) build off this work to suggest that a decrease in criterion variables associated with personal insight (e.g. self-esteem, self-efficacy) after a service-learning course may not be a negative effect because these changes represent a more realistic self-image. Though this may be true, predicting the direction of expected changes in the criterion as a result of service-learning classes is absolutely necessary in order to grasp the impact and evaluate effectiveness.

Psychological Capital. The positive psychology movement lead researchers to focus not only on mental illness, for example depression and schizophrenia, but on psychological issues that have a positive impact on people's live, for example happiness (Diener, 2000), optimism (Seligman, 1998), and hope, (Snyder, 2002). From this foundation, researchers also began applying the ideas of positive psychology to organizations. Specifically, the movement of Positive Organizational Behavior (POB), which was introduced by Luthans (2002a), initiated a call to conduct rigorous research, as is done in the fields of psychology and the social sciences, to investigate the potential impact positive psychology could have on organizational behavior. In this effort, the conception of POB to create a scientifically measurable impact on leadership and human resource development within organizations was initiated by five criteria for inclusion (Luthans, Youssef, et al., 2007):

1. Constructs must be positively-oriented (as opposed to negatively-oriented)

2. Positive constructs that are theoretically-based and empirically researched

3. Measurable with an assessment-tool that had been found reliable and valid in scientific research

4. Be able to be developed, that is, people must be able to learn them

5. Be related to performance and relevant organizational outcomes, for example job satisfaction

The desire to focus on positive psychological constructs helps organizational behavior pivot from the disease model often used in psychology research. Instead of focusing on only helping people overcome their deficits in order to achieve "normal behavior", the first inclusion criterion for POB is that the constructs be positively-oriented. This criterion helps researchers flip the paradigm to developing positive psychological capacities that will help people achieve greater than average organizational outcomes (Luthans, Youssef, et al., 2007) because sustainable organizations require more than average performance (Podsakoff \& MacKenzie, 1997).

The second criterion for inclusion ensures that the scientific rigor that had been applied to the study of mental illnesses would also be applied to the study of positive psychological constructs in organizations. The impact of this criterion provides the foundation for which experimentally-based research can be conducted. If the goal is to develop interventions that cause changes, then they must be based on well-constructed research-based theories.

Measurement is the foundation for scientific inquiry. Researchers must be able to reliably measure the constructs with assessments that meet validation standards in order to advance scientific inquiry. The third criterion for inclusion ensures that scientific research can be conducted with established measures. 
Trait psychology postulates that people have enduring individual differences in the way they think, feel, and act (Costa \& McCrae, 2008). Trait-like constructs are thus enduring and are relatively stable over time (Judge, Higgins, Thorese, \& Barrick, 1999) and are significantly predicted by biological genes, ranging from $41 \%$ to $61 \%$ for the five-factor model (Jang, Livesley, \& Vemon, 1996) and approximately 50\% for general cognitive ability (Plomin, 1999). The fourth criterion for inclusion for POB required that the construct be relatively more malleable than trait-like constructs. Both the five-factor model, also known as the "The BigFive," and general mental ability are considered trait-like constructs that have relatively strong predictive power in terms of career success but are relatively stable over one's lifespan (Judge et al., 1999). Including factors that can be developed is an important characteristic in professional development contexts, where the goal of a training session or intervention is to change the way people think and act.

The last criterion for inclusion of positive constructs into POB is that they must be related to performance and relevant organizational outcomes. Accountability is a key concern in organizations, and justification must be provided to ensure training and development investments are producing measurable results.

Based on the inclusion criteria, the four constructs initially included within POB are hope, efficacy/confidence, resilience, and optimism and led to new thinking about capital in organizations, positive psychological capital (PsyCap; Luthans, et al., 2004; Luthans \& Youssef, 2004). Creating a competitive advantage using a resource-based model, for example, increasing resources and capital to enhance performance, is not a new concept in enhancing organizational performance (see Peteraf, 1993 for example), and there are many different types of capital. For example, creating a competitive advantage to increase organizational performance has been linked to economic capital (Cooper, Gimeno-Gascon, \& Woo, 1994), social capital (Lepak \& Snell, 1999), and human capital (Kim \& Ployhart, 2014). Luthans and colleagues (2004) present a framework for understanding the different types of capital used to create a competitive advantage: (a) economic capital is what you have (i.e. finances, tangible assets); (b) human capital is what you know (i.e. experience, education, skills); (c) social capital is who you know (i.e. relationships, contacts, friends); and (d) psychological capital is who you are and what you can become (hope, efficacy/confidence, resilience, and optimism). PsyCap moves beyond one's relatively stable individual resources to provide a framework for individual development from the actual self to the possible self (Avolio \& Luthans, 2005). PsyCap provides the framework for not only understanding why a person might set challenging goals and believe he/she can achieve them (efficacy), expect he/she will achieve challenging goals (optimism), find the will and the way to achieve goals (hope), and overcome setbacks to achieve goals (resilience), but PsyCap also provides the framework for developing these psychological capital resources within individuals to create a competitive advantage for organizations.

Through empirical POB research, the four constructs of hope, efficacy/ confidence, resilience, and optimism - measured with empirically researched assessment tools that were modified for workplace settings (Luthans, Youssef, et al., 2007) - were reported to be empirically linked to one higher-order, core construct, PsyCap, (Luthans, Youssef, et al., 2007; Luthans, Avolio, et al., 2007). Luthans, Avolio, et al. (2007) reported that the combined success 
of the higher-order, core construct of PsyCap is greater than the success calculated by summing up the impact of the four constructs individually. The theoretical mechanism of this success is due to the core construct of PsyCap, which is "one's positive appraisal of circumstances and probability for success based on motivated effort and perseverance" (Luthans, Avolio, et al., 2007, p. 550). Thus, PsyCap is a higher-order core construct that consists of four lower-order constructs - hope, efficacy, resilience, and optimism - and to provide more depth to the discussion of PsyCap, a review of each of the four components is provided in the following section.

Self-Efficacy/Confidence. Self-efficacy/confidence is likely the most established construct within PsyCap, as this construct is deeply based on the work of Bandura (1986; 1997 , 2001). The empirical link between self-efficacy and performance in a variety of contexts is well established through the use of meta-analyses (see Moritz, Feltz, Fahrbach, \& Mack, 2000 for sports performance; Multon, Brown, \& Lent, 1991 and Richardson, Abraham, \& Bond, 2012 for academic performance; Stajkovic \& Luthans, 1998 for workplace performance; and Stajkovic, Lee, \& Nyberg, 2009 for group performance).

The measurement of PsyCap self-efficacy/confidence is based on the theoretical work of Bandura (1986, 1997, 2001), and the measurement of the PsyCap construct was based on Parker's (1998) research focusing on work role self-efficacy. Parker's (1998) measure, which focuses on the workplace self-efficacy related to proactivity, interpersonal skills, and operating across organizational boundaries is more state-like than the universal trait-like measures of generalized self-efficacy (Scholz, Doña, Sud, \& Schwarzer, 2002). Parker's (1998) measure of self-efficacy met the key POB inclusion criteria of being based on a positive state-like developmental - construct, and the measurement tool had also been developed using rigorous psychometric methods.

Hope. The development of hope as a modern positive psychological construct developed from an initial, and long standing view that hope was "the perception that one can reach desired goals" (Snyder, Rand, \& Sigmon, 2002, p. 257) to "a cognitive set that is based on a reciprocally derived sense of successful (a) agency (goal-directed determination) and (b) pathways (planning of ways to meet goals)" (Snyder, Irving, \& Anderson, 1991, p. 571). Pathway thinking and agency thinking act iteratively and additively to increase the likelihood of goal achievement. In other words, those who have hope have the will (willpower) and the way (pathways or waypower) to achieve their goals (Luthans, Youssef, et al., 2007).

The relationship between hope and a number of significant outcomes is well established (for example, life satisfaction, Bailey, Eng, Frisch, \& Snyder, 2007; college academic achievement, Snyder et al. 2002; sport achievement, Curry, Snyder, Cook, Ruby, \& Rehm, 1997; workplace engagement, Ouweneel, Le Blanc, Schaufeli, \& Wijhe, 2012), including, and perhaps most importantly for the study of POB, a recent meta-analysis reporting the positive link between hope and workplace performance (Reichard, Avey, Lopez, \& Dollwet, 2013). 
The consideration of measuring hope is important, in that hope is conceptualized and is measured as both a trait-like (Snyder et al., 1991) and state-like (Snyder et al., 1996) construct. Empirical evidence suggests that these two measures have sound psychometric properties (Snyder, 2002), but the state measure of hope fits the POB inclusion criteria. State hope is more malleable than trait hope because state hope is focused on more proximal events and time (Snyder et al., 1996). The measure of state hope has demonstrated strong support for internal reliability and convergent and discriminate validity with several key variables (see Snyder et al., 2002 and Lopez, Ciarlelli, Coffman, Stone, \& Wyatt, 2000 for a review), including trait hope (Snyder et al., 1996; Feldman, Rand, \& Kahle-Wrobleski, 2009).

Optimism. The conceptual framework for optimism is based on explanatory or attributional style of the cause of events (Peterson \& Steen, 2002). Pessimists would attribute the cause of negative events to internal factors that cannot be easily changed, whereas optimists would attribute the cause of negative events to external factors that are temporary. In terms of positive events, optimists would attribute the cause as internal, relatively permanent factors, whereas pessimists would attribute the cause of positive events to external, temporary factors (Seligman, 1998). Stated another way, optimists believe that they are the cause of positive events, and that negative events are caused by situation-specific factors; whereas, pessimists believe that they are the cause of negative events, and that positive events are caused by chance. The relationship between optimism with physical health and subjective well-being is wellestablished (see Carver \& Scheier, 2002 and Carver, Scheier, \& Segerstrom, 2010 for a review), including a recent study demonstrating that relatively more optimistic women live longer (Engberg et al., 2013). Optimism has a demonstrated relationship to performance, both in academics (Peterson \& Barrett, 1987) and in the workplace (Luthans, Lebsack, \& Lebsack, 2008; Medlin \& Green, 2009; Seligman, 1998). The measure of optimism included within PsyCap is based on Scheier and Carver's (1985) measure and was adapted for a work setting (Luthans, Youssef, et al., 2007; Luthans, Avolio, et al., 2007).

Resilience. A considerable amount of work in clinical and developmental psychology has focused on the resilience of children and youth (see Masten, 2014 for a review), and in this work, resilience is defined as the capacity to adapt and rebound from adverse events (Masten \& Reed, 2002). PsyCap resilience broadens this conceptualization in two ways (Luthans, Youssef, et al. 2007). First, PsyCap resilience includes not simply "bouncing back" from adversity, but also includes rebounding from positive change (for example, a new job; Luthans, 2002a). Second, PsyCap does not limit resilience to simply "bouncing back" to a level of normality because resilience can also have the impact of helping people rebound beyond "normality" to higher levels of performance because overcoming positive and negative challenges can build capacity (Sutcliffe \& Vogus, 2003; Luthans, Vogelgesang, \& Lester, 2006). The measurement of PsyCap resilience is based on the work of Wagnild and Young (1993), and like the PsyCap optimism scale, the resilience scale had to be adapted for a general workplace setting. Broadly, research on individual resilience has focused on what causes some people to overcome adversity and challenges, and what prevents some people to fail to overcome adversity (Masten, 2014). At the time Luthans formulated PsyCap, research linking developmental resilience with workplace performance was rather limited (Sutcliffe \& Vogus, 2003, Youssef \& Luthans, 2007), however, since that time the study of resilience as a component of PsyCap (Newman, Ucbasaran, Zhu, \& 
Hirst, 2014) and within positive organizational scholarship (POS; Lengnick-Hall, Beck, \& Lengnick-Hall, 2011; Richtnér \& Löfsten, 2014) has flourished. In all three streams of research mentioned (POB, POS, and clinical and developmental psychology), resilience is considered state-like and has the potential to be developed within individuals (POB, Luthans, Avolio, et al., 2007; POS, Sutcliffe \& Vogus, 2003; clinical and developmental psychology, Masten, 2014).

PsyCap Outcomes. Since the formulation of PsyCap, a tremendous amount of research has explored the construct, and in recent years researchers have begun to take a step back to review the work completed thus far, including a meta-analysis (Avey, Reichard, \& Luthans, Mhatre, 2011), two reviews (a psychometric review Dawkins, Martin, Scott, \& Sanderson, 2013 and a general review, Newman et al., 2014), and a special issue dedicated to the topic in the Journal of Leadership \& Organizational Studies (Luthans \& Avolio, 2014). The meta-analysis conducted by Avey and colleagues (2011) provide strong empirical evidence to support the significant relationship between PsyCap and a number of key workplace outcomes. The relationship between PsyCap and negative workplace attitudes including cynicism $(\rho=-.49,95 \%$ $[--.55,-.42])$, turnover intention $(\rho=-.32,95 \%[-.36,-.28])$, and stress/anxiety $(\rho=-.29,95 \%[-$ $.34,-.24])$ were negative - the expected direction. PsyCap was also positively related to workplace relevant outcomes, including work satisfaction $(\rho=.54,95 \%[.50, .57])$, commitment $(\rho=0.48,95 \%[.44, .52])$, and psychological well-being $(\rho=.57,95 \%[.51, .62])$. The relationships between PsyCap and workplace behaviors were also significant and in the expected direction, including organizational citizenship behaviors (OCB; $\rho=.45,95 \%[.41, .50]$ ), workplace performance $(\rho=.26,95 \%[.24, .29])$, and deviance $(\rho=-.42,95 \%[-.47,-.38])$.

Measuring PsyCap. The most recent review of PsyCap (Newman et al., 2014) stated that out of the 60 empirical PsyCap studies, 33 used the PsyCap Questionnaire (PCQ), a 24-item scale (Luthans, Youssef, et al., 2007). The PCQ uses six items based on previously created scales that had demonstrated strong reliability and validity to measure each of the four constructs: hope (Snyder et al., 1996), efficacy/confidence (Parker, 1998), resilience (Wagnild \& Young, 1993), and optimism (Scheier \& Carver, 1985). A 12-item shortened scale (PCQ-12) has also been used in research (Luthans, Avey, Clapp-Smith, \& Li, 2008). However, as Newman et al. (2014) discuss, one major concern with the PCQ is the potential for social desirability to impact the results. People may be more apt to answer the items in a way that will help them "look good." Harms and Luthans (2012b) reported on the use of an implicit measure of PsyCap (I-PCQ), was related to several workplace factors (e.g. job performance, job satisfaction), but it was less susceptible to response bias.

Developing PsyCap. The developmental nature of PsyCap is at the foundation of the theory, and although the hope, efficacy/confidence, resilience, and optimism may be conceived of as trait-like, there is growing evidence that the constructs, as conceived and measured within the PsyCap formulation, are indeed state-like - developmental (Demerouti, van Eewijk, Snelder, \& Wild, 2011; Luthans, Luthans, \& Jensen, 2012; Luthans, 2012). The initial empirical evidence supporting the state-like nature of PsyCap compared the test-retest reliabilities of conscientiousness, core self-evaluations (both considered trait-like), PsyCap (state-like), and a positive emotions measure (considered more state-like than PsyCap), and the calculated reliabilities aligned with the expected order, where conscientiousness and core self-evaluations 
had the highest reliabilities (.76 and .81 respectively), followed by PsyCap (.52) and positive emotions (.46; Luthans, Avolio, et al., 2007).

Luthans, Avey, Avolio, and Peterson (2010) describe one example of a PsyCap intervention focused on goal-setting derived from hope theory (Snyder, 2000). Hope consists of both agency - a belief that one has control over achieving goals - and pathways thinking identifying various avenues available to achieve goals (Snyder et al., 1991). The first step was for the participants to create a personal goal, followed by facilitators helping participants increase agentic capacity. To increase agentic capacity, the facilitators used several activities drawn from both hope theory (Snyder \& Taylor, 2000) and self-efficacy theory (Bandura, 2008), for example, one activity helped participants divide large goals into smaller, manageable pieces. Next, facilitators led small group discussions focused on increasing pathway thinking. The small group discussions provided participants with additional pathways to accomplish their respective goals. Luthans et al. (2010) theorized that by using these goal-setting activities to increase agentic capacity and pathway thinking (hope), participants would have increased confidence in their abilities to achieve goals (efficacy), positive expectations of success (optimism), and increased ability to foresee and overcome obstacles (resilience), thus increasing overall PsyCap. As expected, the results from the study indicated that participants' level of PsyCap increased after the two-hour intervention (Luthans et al., 2010).

\section{Theoretical Framework for Linking Service-Learning and PsyCap}

Using a service-learning course titled, "Interpersonal Skills for Leadership" as an example, the following section will provide a theoretical connection between activities in a leadership service-learning course with PsyCap developmental activities (Luthans, Avey, Avolio, Norman, \& Combs, 2006; Luthans et al., 2010). Three specific elements of the course, goalsetting, written reflections, and presentations and updates are reviewed.

The service associated with the course provides the context for learning to occur. Some instructors explain that the service project is the "lab" for the class, where students get to practice the skills that are covered in the course content. The focus of this theoretical review is the integration of the service experience with goal-setting, reflections, and presentations and updates, providing an outline of how these specific elements in the service-learning course are related to developing hope, efficacy, resilience, and optimism; Table 1 summarizes the following discussion.

Goal-Setting. In the service-learning course, students spend a significant amount of time focusing on goal-setting. The goal-setting method used in the service-learning course are STEAM goals, goal s that are specific, time-oriented, ensure success, action-oriented, and measurable (Fritz, Brown, Povlacs Lunde, \& Banset, 2005).

"Specific goals" are more precise than non-specific goals. For example, a goal that states "I will become better at communicating" is less specific than a goal that states "I will become better at actively listening when I'm engaging in my service learning project." Communicating in this example is rather vague because of the many different aspects of communication. For 
example, the goal of becoming "better at communicating" could focus on a variety of activities, including giving presentations, talking one-on-one, and writing e-mails. The broadness of the goals would make it difficult for the person setting the goal to know whether or not their goal was achieved because of the many different possible interpretations. However, a focus on activelistening, a specific component of effective communication provides for adequate specificity. Students are encouraged to choose specific goals associated with interpersonal skills covered in the course content (e.g. active listening, nonverbal communication, time management, handling stress, building trust, resolving conflict, responding with empathy, and cross-cultural communication).

"Time-oriented" goals have a specific time-limit. Using the example from above, "I will become better at actively listening when I'm engaging in my service learning project" does not explicitly include time specificity. However, restating the goal as "I will become better at actively listening during my 20 hour service-learning project this semester" would be much more time-specific. In this example, it is clear that the service project is 20 hours long and that the goal needs to be achieved by the end of the semester.

"Ensuring success" refers to creating goals that are both realistic and desirable. Creating realistic goals ensures that a person can actually accomplish the goals. For example, setting a goal to "become the best active listener in the class" would be unrealistic for several reasons. First, it would be very difficult to determine who the best active listener in the class was. Second, there is no way for the person setting this goal to control how good everyone else in the class is at active listening.

The second aspect of "ensuring success" is that goals must be desirable. Desirable goals are something that a person wants to achieve. In the examples given, the person creating the goal would actually want to become a better active listener, and to help reinforce this goal, the person would articulate reasons to accomplish the goals, for example: "I want to be a better active listening because it will help me work with my clients better, it will help me better understand my clients, and it will help my clients feel valued because they will be listened to." 
Table 1.

PsyCap Development Based on Elements of Service-Learning Course

\begin{tabular}{|c|c|c|c|}
\hline & Goal-Setting & Reflections & Presentations and Updates \\
\hline Hope & $\begin{array}{l}\text { - Specific goals lead to clear } \\
\text { conceptualization of goal. } \\
\text { - Action steps can promote } \\
\text { pathway analysis. } \\
\text { - Desirable goals provide } \\
\text { source of motivation and } \\
\text { willpower. }\end{array}$ & - Increased agency. & $\begin{array}{l}\text {-Pathway creation by } \\
\text { listening to others. }\end{array}$ \\
\hline Optimism & $\begin{array}{l}\text { - Goals promote positive } \\
\text { expectancy. }\end{array}$ & $\begin{array}{l}\text {-Promotes realistic } \\
\text { view of past events. } \\
\text {-Promote positive } \\
\text { expectancy by } \\
\text { stating how lessons } \\
\text { learned will be used } \\
\text { in the future. }\end{array}$ & $\begin{array}{l}\text {-Presenting success } \\
\text { promotes positive } \\
\text { expectancy. } \\
\text {-Feedback and questions } \\
\text { can promote realistic } \\
\text { appraisals. }\end{array}$ \\
\hline Resilience & $\begin{array}{l}\text {-Action steps can help } \\
\text { identify obstacles. }\end{array}$ & $\begin{array}{l}\text { - Building capacity } \\
\text { to recognize and } \\
\text { identify obstacles. }\end{array}$ & $\begin{array}{l}\text {-Provides opportunity to } \\
\text { build social support } \\
\text { network. } \\
\text {-Building capacity to } \\
\text { recognize obstacles. }\end{array}$ \\
\hline $\begin{array}{l}\text { Efficacy/ } \\
\text { Confidence }\end{array}$ & $\begin{array}{l}\text {-Action steps help create } \\
\text { opportunities for } \\
\text { incremental success. }\end{array}$ & $\begin{array}{l}\text {-Increased agency. } \\
\text { - Identifying success. }\end{array}$ & $\begin{array}{l}\text {-Vicarious learning from } \\
\text { the success of others. } \\
\text { - Sharing success builds } \\
\text { confidence. }\end{array}$ \\
\hline
\end{tabular}

"Action-oriented" goals have steps outlining how to achieve the goals. Building off of the active listening goal, a person could create steps to help them achieve their goal. For example, to become better at active listening, each time I am at my service project, I will engage in a conversation with at least one person. When I am engaged in conversation I will demonstrate active listening by paraphrasing what the other person says, by asking questions, and by demonstrating the proper body language, for example head nodding. All of these are steps outlining the pathway for becoming a better active listener.

"Measurable" goals must be met using quantifiable behaviors. For example, "I will become a better active listener" is not clearly measurable. However, using the action steps provided earlier, behavioral goals could be created. For example, "After each interaction I have 
with my first three clients, I will keep track of how many times I paraphrase, asked questions, and demonstrated proper body language. At the beginning and end of each week, I will re-record this information with the first three clients of the day. I will know that I've successfully accomplished my goal when, at the end of the semester, I have increased the number of times I paraphrased, asked questions, and demonstrated proper body language 20 percent more often than when I started.

The purpose of focusing on STEAM goals in the service-learning course are to ensure that students learn how to create effective goals. Creating goals that meet the STEAM standards are more motivating and increase the likelihood for success (Fritz et al., 2005). STEAM goals also meet the key components of effective goals as suggested by Locke and Latham (2006), in that the goals are specific and challenge the students to stretch themselves.

Developing hope, optimism, and self-efficacy are all theoretically linked through the focus on goal-related thinking (Snyder et al., 2002). Developing hope includes, at least in part, a clear conceptualization of goals, creating pathways to attain goals, and finding the motivation to focus on achieving the goal (Lopez, Floyd, Ulven, \& Snyder, 2000). In relation to developing hope, STEAM goals focus on all three components of hope development. Writing goals ensures students are conceptualizing their goals. Creating action steps helps students think through their goals from start to finish, ensuring that they outline the pathways to achievement. When students focus on "ensuring success," specifically creating goals that are desirable, students provide the motivational foundation to sustain the required energy to follow through on their goals.

By focusing on the successful completion of goals, students are promoting the positive, optimistic expectancy. Creating action steps for goals helps students identify potential obstacles, building resilience. The action steps also help students create opportunities for incremental success, promoting efficacy. The goal-setting strategy in the service-learning course, creating STEAM goals, provides significant opportunities to promote each element of PsyCap.

Reflections. Using reflection activities within service-learning courses is a major factor in achieving learning outcomes (Conway et al., 2009; Knapp et al., 2010; Parker-Gwin \& Marbry, 1998; Strage, 2000; Yorio \& Ye, 2012), and these activities can also impact the development of PsyCap. The written reflection format used in the service-learning course consists of three parts - What, So What, and Now What. This reflection format is widely used in higher education to support service-learning outcomes (Connors \& Seifer, 2005), and it is based on Kolb's experiential learning cycle (2005):

Immediate or concrete experiences are the basis for observations and reflections. These reflections are assimilated and distilled intro abstract concepts from which new implications for actions can be drawn. These implications can be actively tests and serve as guides in creating new experiences (p. 194).

The "What" section requires students to recount concrete events from their service experiences. The "So What" section requires students to reflect on how they responded to the events, both behaviorally and affectively. The "Now What" section requires students to reflect 
on how they can use the information they have now just reflected on and apply it to future situations to help them achieve their goals. These activities enable students to impact PsyCap in several ways. First, as Seligman (1998) suggests, reflecting on a situation can lead to a more realistic view of the events. Second, ensuring that students write about the lessons they learned from each event and reflecting on how to apply those lessons to a future situation, students are developing optimistic expectancy. Third, focusing on what aspects of the situation were influenced by the students actions and emotions (using the "So What" section), and developing a plan to use the lessons in the future (using the "Now What" section), students are developing agency. Fourth, students are expected to reflect on events where they successfully used their interpersonal skills. Reflecting on their success helps students build efficacy and confidence in using their skills. Also, by reflecting on the successes and failures of past events, students are building capacity to recognize and identify obstacles.

Presentations and Updates. Throughout the course, students must provide updates about their service projects. Some of these updates are only a few minutes long, while other presentations can be five to 10 minutes in length. Many of the expected outcomes associated with reflections are also be expected by creating presentations. Thus, for sake of parsimony, this discussion focuses on the act of presenting or listening to presentations, and not necessarily the preparation of the presentation.

Participating in strategy discussions about completing tasks has been linked to higher levels of task completion by promoting new ideas - pathways - on how to complete the task (Latham, Winters, \& Locke, 1994; Locke \& Latham, 2002). Correspondingly, listening to other students present about how they achieved or did not achieve their goals provides students with the opportunity to recognize additional pathways. By listening to other students present, there is not only an opportunity to recognize obstacles, but there is also an opportunity to build a network of people with similar experiences to provide support. In general, sharing stories about goals also provides opportunities for vicarious learning.

Giving presentations can also promote development. Specifically, sharing success in a group setting helps promote confidence and positive expectancy. Also, receiving feedback and questions from peers who have gone through similar experiences, provides opportunities for more realistic appraisals of events.

\section{Conclusion}

The purpose of this review was to demonstrate the theoretical connection of the potential impact a leadership service-learning course could have on an important workplace relevant outcome, PsyCap. It is undeniable that many of activities in the course were chosen or "cherrypicked" to support the theoretical foundation that PsyCap is developed during the course, as there are learning outcomes and activities students engaged in that are not included in this review of the course. The goal was to provide a theoretical outline of how the course could develop PsyCap by drawing clear connections between course activities and the theories of hope, efficacy, resilience, and optimism development. Although developing PsyCap has not been an 
explicit learning outcome, the examples of the course activities do demonstrate that, if PsyCap can be developed as theorized (Luthans et al., 2006; Luthans, Youssef, et al., 2007), this course should help students increase their PsyCap.

Finally, given that a theoretical foundation for developing PsyCap in a leadership servicelearning course has been provided, several recommendations arise. First, testing the development of PsyCap, using of the well-tested measures of PsyCap, in a service-learning course that includes some of the activities listed using pre/post-test design could provide quantifiable evidence of the theoretical connection. Second, purposefully and explicitly incorporating activities used in PsyCap development in service-learning could help promote student career preparedness. Third, trait-like variables that are linked to career success, for example, Core SelfEvaluations (Judge \& Bono, 2001; Judge, Erez, Bono, \& Thoresen, 2003), should also be explored to determine the developmental impact service-learning can provide. There could be limits of the measurable impact of service-learning, such that, although PsyCap could be developed over the course of a semester, a more trait-like characteristic would not be developed.

\section{References}

Avey, J. B., Reichard, R. J., Luthans, F., \& Mhatre, K. H. (2011). Meta-analysis of the impact of positive psychological capital on employee attitudes, behaviors, and performance. Human Resource Development Quarterly, 22(2), 127-152.

Avolio, B. J., \& Luthans, F. (2005). The high impact leader. McGraw Hill Professional.

Bailey, T. C., Eng, W., Frisch, M. B., \& Snyder†, C. R. (2007). Hope and optimism as related to life satisfaction. The Journal of Positive Psychology,2(3), 168-175.

Bandura, A. (1986). Social foundations of thought and action: A cognitive social theory. Pretince Hall, Englewood Cliffs, New York.

Bandura, A. (1997). Self-efficacy: The exercise of control. New York, NY: Freeman.

Bandura, A. (2001). Social cognitive theory: An agentic perspective. Annual review of psychology, 52(1), 1-26.

Bandura, A. (2008). An agentic perspective on positive psychology. In S. J. Lopez (Ed.), Positive psychology: Exploring the best in people (Vol. 1, pp. 167-196).

Westport, CT: Greenwood Publishing.

Bernacki, M. L., \& Jaeger, E. (2008). Exploring the impact of service-learning on moral development and moral orientation. Michigan Journal of Community Service Learning, 14, 5-15. 
Bono, J. E., \& Judge, T. A. (2003). Core self-evaluations: A review of the trait and its role in job satisfaction and job performance. European Journal of Personality, 17, S5-S18.

Boss, J. (1994). The effect of community service work on the moral development of college ethics students. Journal of Moral Education, 23, 183-197.

Bringle, R. G., \& Steinberg, K. (2010). Educating for informed community involvement. American Journal of Community Psychology, 46(3-4), 428-441.

Carver, C. S., Scheier, M. F., \& Segerstrom, S. C. (2002). Optimism. In C. R. Snyder \& S. J. Lopez (Eds), Handbook of positive psychology, (pp. 231-243). New York, NY: Oxford University Press.

Carver, C. S., Scheier, M. F., \& Segerstrom, S. C. (2010). Optimism. Clinical Psychology Review, 30, 879-889.

Connors, K., \& Seifer, S. D. (2005). Reflection in higher education service-learning. Retrieved from https://www.nationalserviceresources.gov/reflection-highereducation-service-learning\#.U6ExSPldWSp

Conway, J. M., Amel, E. L., \& Gerwien, D. P. (2009). Teaching and learning in the social context: A meta-analysis of service learning's effects on academic, personal, social, and citizenship outcomes. Teaching of Psychology, 36(4), 233-245.

Cooper, A. C., Gimeno-Gascon, F. J., \& Woo, C. Y. (1994). Initial human and financial capital as predictors of new venture performance. Journal of Business Venturing, 9(5), 371-395.

Costa, P., \& McCrae, R. (2008). The revised NEO personality inventory (NEO-PI-R). In G. Boyle, G. Matthews, \& D. Saklofske (Eds.), The SAGE handbook of personality theory and assessment: Volume 2 - Personality measurement and testing. (pp. 179-199). London: SAGE Publications Ltd. doi:10.4135/9781849200479.n9

Dawkins, S., Martin, A., Scott, J., \& Sanderson, K. (2013). Building on the positives: A psychometric review and critical analysis of the construct of psychological capital. Journal of Occupational and Organizational Psychology, 86, 348-370.

Demerouti, E., van Eeuwijk, E., Snelder, M., \& Wild, U. (2011). Assessing the effects of a "personal effectiveness" training on psychological capital, assertiveness and self-awareness using self-other agreement. Career Development International, 16, 60-81. 
Diener, E. (2000). Subjective well-being: The science of happiness and a proposal for a national index. American psychologist, 55(1), 34.

Einfeld, A., \& Collins, D. (2008). The relationships between service-learning, social justice, multicultural competence, and civic engagement. Journal of College Student Development, 49(2), 95-109.

Engberg, H., Jeune, B., Andersen-Ranberg, K., Martinussen, T., Vaupel, J. W., \& Christensen, K. (2013). Optimism and survival: does an optimistic outlook predict better survival at advanced ages? A twelve-year follow-up of Danish nonagenarians. Aging Clinical and Experimental Research, 25(5), 517-525.

Feldman, D. B., Rand, K. L., \& Kahle-Wrobleski, K. (2009). Hope and goal attainment: Testing a basic prediction of hope theory. Journal of Social and Clinical Psychology, 28(4), 479-497.

Fritz, S., Brown, F. W., Lunde, J. P., \& Banset, E. A. (2005). Interpersonal skills for leadership $2^{\text {nd }}$ Edition. Upper Saddle River, NJ: Prentice Hall.

Govekar, M. A., \& Rishi, M. (2007). Service learning: Bringing real-world education into the b-school classroom. Journal of Education for Business, 83, 3-10.

Gray, M. J., Ondaatje, E. H., Fricker Jr, R. D., \& Geschwind, S. A. (2000). Assessing Service-Learning: Results Froma a Svervy of "Learn and Serve America, Higher Education”. Change: The Magazine of Higher Learning, 32(2), 30-39.

Jang, K. L., Livesley, W. J., \& Vemon, P. A. (1996). Heritability of the big five personality dimensions and their facets: a twin study. Journal of personality, 64(3), 577-592.

Judge, T. A., \& Bono, J. E. (2001). Relationship of core self-evaluations traits-selfesteem, generalized self-efficacy, locus of control, and emotional stability-with job satisfaction and job performance: A meta-analysis. Journal of Applied Psychology, 86, 80-92.

Judge, T. A., Erez, A., Bono, J. E., \& Thoresen, C. J. (2003). The core self-evaluations scale: Development of a measure. Personnel Psychology, 56, 303-331.

Judge, T. A., Higgins, C., Thoresen, C. J., \& Barrick, M. R. (1999). The Big Five personality traits, general mental ability, and career success across the life span. Personnel Psychology, 52, 621-652.

Keen, C., \& Hall, K. (2009). Engaging with difference matters: Longitudinal student outcomes of co-curricular service-learning programs. The Journal of Higher Education, 80(1), 59-79. 
Kim, Y., \& Ployhart, R. E. (2014). The effects of staffing and training on firm productivity and profit growth before, during, and after the great recession. Journal of Applied Psychology. 99(3), 361-389.

Kolb, A. Y., \& Kolb, D. A. (2005). Learning styles and learning spaces: Enhancing experiential learning in higher education. Academy of Management Learning and Education, 4(2), 193-212.

Knapp, T., Fisher, B., \& Levesque-Bristol, C. (2010). Service-learning's impact on college Students' commitment to future civic engagement, self-efficacy, and social empowerment. Journal of Community Practice, 18(2-3), 233-251.

Latham, G. P., Winters, D. C., \& Locke, E. A. (1994). Cognitive and motivational effects of participation: A mediator study. Journal of Organizational Behavior, 15(1), 49-63.

Lepak, D. P., \& Snell, S. A. (1999). The human resource architecture: Toward a theory of human capital allocation and development. Academy of Management Review, 24(1), 31-48.

Lewis, T. L. (2004). Service learning for social change? Lessons from a liberal arts college. Teaching Sociology, 32(1), 94-108.

Locke, E. A., \& Latham, G. P. (2002). Building a practically useful theory of goal setting and task motivation: A 35-year odyssey. American Psychologist, 57(9), 705.

Locke, E. A., \& Latham, G. P. (2006). New Directions in Goal-Setting Theory.Current Directions in Psychological Science, 15(5), 265-268.

Lopez, S. J., Ciarlelli, R., Coffman, L., Stone, M., \& Wyatt, L. (2000). Diagnosing for strengths: On measuring hope building blocks. In C. R. Snyder (Ed.), Handbook of hope: Theory, Measures, and interventions (pp. 57-85). San Diego: Academic Press.

Lopez, S. J., Floyd, R. K., Ulven, J. C., \& Snyder, C. R. (2000). Hope therapy: Helping clients build a house of hope. In C. R. Snyder (Ed.), Handbook of hope: Theory, measures, and applications (pp. 123-150). San Diego, CA: Academic.

Luthans, B. C., Luthans, K. W., \& Jensen, S. (2012). The impact of business school students' psychological capital on academic performance. Journal of Education for Business, 87, 253-259.

Luthans, F. (2002a). The need for and meaning of positive organizational behavior. Journal of Organizational Behavior, 23, 695-706. 
Luthans, F. (2012). Psychological capital: Implications for HRD, retrospective analysis, and future directions. Human Resource Development Quarterly, 23(1), 1-8.

Luthans, F., Avey, J. B., Avolio, B. J., Norman, S., Combs, G. (2006). Psychological capital development: Toward a microintervention. Journal of Organizational Behavior, 27, 387 393.

Luthans, F., Avey, J. B., Avolio, B. J., \& Peterson, S. J. (2010). The development and resulting performance impact of positive psychological capital. Human Resource Development Quarterly, 21, 41-67.

Luthans, F., Avey, J. B., Clapp-Smith, R., \& Li, W. (2008). More evidence on the value of Chinese workers' psychological capital: A potentially unlimited competitive resource? International Journal of Human Resource Management, 19, 818-827.

Luthans, F., \& Avolio, B. J. (2014). Brief summary of psychological capital and introduction to the special issue. Journal of Leadership \& Organizational Studies, 21(2), 125-129.

Luthans, F., Avolio, B., Avey, J. B., \& Norman, S. M. (2007). Psychological capital: Measurement and relationship with performance and job satisfaction. Personnel Psychology, 60, 541-572.

Luthans, K. W., Lebsack, S. A., \& Lebsack, R. R. (2008). Positivity in healthcare: relation of optimism to performance. Journal of Health Organization and Management, 22(2), 178-188.

Luthans, F., Luthans, K. W., Luthans, B. C. (2004). Positive psychological capital: Beyond human and social capital. Business Horizons, 47(1), 45-50.

Luthans, F., Vogelgesang, G. R., \& Lester, P. B. (2006). Developing the psychological capital of resiliency. Human Resource Development Review, 5(1), 25-44.

Luthans, F., \& Youssef, C. M. (2004). Human, social, and now positive psychological capital management. Organizational Dynamics, 33, 143-160.

Luthans, F., \& Youssef, C. M. (2007). Emerging positive organizational behavior. Journal of Management, 33, 321-349.

Luthans, F., Youssef, C. M., \& Avolio, B. J. (2007). Psychological capital: Developing the human competitive edge. Oxford, UK: Oxford University Press.

Madsen, S. R. (2004). Academic service learning in human resource management education. Journal of Education for Business, 79(6), 328-332. doi:

10.3200/JOEB.79.6.328-332 
Markus, G. B., Howard, J. P., \& King, D. C. (1993). Notes: Integrating community service and classroom instruction enhances learning: Results from an experiment. Educational Evaluation and Policy Analysis, 15(4), 410-419.

Masten, A. S. (2014). Global perspectives on resilience in children and youth.Child Development, 85(1), 6-20.

Masten, A. S., \& Reed, M. G. J. (2002). Resilience in development. In C. R. Snyder \& S. Lopez (Eds.), Handbook of positive psychology (pp. 74-88). Oxford, UK: Oxford University Press.

Medlin, B., \& Green Jr, K. W. (2009). Enhancing performance through goal setting, engagement, and optimism. Industrial Management \& Data Systems, 109(7), 943 956.

Moely, B. E., McFarland, M., Miron, D., Mercer, S., \& Ilustre, V. (2002). Changes in college students' attitudes and intentions for civic involvement as a function of service-learning experiences. Michigan Journal of Community Service Learning, 9, 18-26.

Moely, B. E., Mercer, S. H., Ilustre, V., Miron, D., \& McFarland, M. (2002). Psychometric properties and correlates of the Civic Attitudes and Skills Questionnaire (CASQ): A measure of students' attitudes related to servicelearning. Michigan Journal of Community Service Learning, 8(2), 15-26.

Moritz, S. E., Feltz, D. L., Fahrbach, K. R., \& Mack, D. E. (2000). The relation of selfefficacy measures to sport performance: A meta-analytic review. Research Quarterly for Exercise and Sport, 71(3), 280-294.

Multon, K. D., Brown, S. D., \& Lent, R. W. (1991). Relation of self-efficacy beliefs to academic outcomes: A meta-analytic investigation. Journal of Counseling Psychology, 38(1), 30.

Myers-Lipton, S. J. (1998). Effect of a comprehensive service-learning program on college students' civic responsibility. Teaching Sociology. 26(4), 243-258.

Newman, A., Ucbasaran, D., Zhu, F., \& Hirst, G. (2014). Psychological capital: A review and synthesis. Journal of Organizational Behavior, 35(S1), S120-S138.

Osborne, R. E., Hammerich, S., \& Hensley, C. (1998). Student effects of servicelearning: Tracking changes across a semester. Michigan Journal of Community Service Learning, 5: 5-13.

Papamarcos, S. D. (2005). Giving traction to management theory: Today's servicelearning. Academy of Management Learning and Education, 4: 325-335. 
Parker, S. (1998). Enhancing role-breadth self-efficacy: The roles of job enrichment and other organizational interventions. Journal of Applied Psychology, 83, 835-852. doi:10.1037//0021-9010.83.6.835

Parker-Gwin, R., \& Mabry, J. B. (1998). Service learning as pedagogy and civic education: Comparing outcomes for three models. Teaching Sociology, 26, 276291.

Peterson, C., \& Barrett, L. C. (1987). Explanatory style and academic performance among university freshman. Journal of Personality and Social Psychology, 53(3), 603.

Peterson, C., \& Steen, T. A. (2002). Optimistic explanatory style. In C. R. Snyder \& S. J. Lopez (Eds), Handbook of positive psychology, (pp. 257-276). New York, NY: Oxford University Press.

Plomin, R. (1999). Genetics and general cognitive ability. Nature, 402, C25-C29.

Podsakoff, P. M., \& MacKenzie, S. B. (1997). Impact of Organizational Citizenship Behavior on Organizational Performance: A Review and Suggestion for Future Research. Human Performance, 10(2), 133.

Reed, V. A., Jernstedt, C. G., Hawley, J. K., Reber, E. S., \& DuBois, C. A. (2005). Effects of a small-scale, very short-term service-learning experience on college students. Journal of Adolescence, 28(3), 359-368.

Reichard, R. J., Avey, J. B., Lopez, S., \& Dollwet, M. (2013). Having the will and finding the way: A review and meta-analysis of hope at work. The Journal of Positive Psychology, 8(4), 292-304.

Richardson, M., Abraham, C., \& Bond, R. (2012). Psychological correlates of university students' academic performance: a systematic review and metaanalysis. Psychological Bulletin, 138(2), 353.

Richtnér, A., \& Löfsten, H. (2014). Managing in turbulence: how the capacity for resilience influences creativity. $R \& D$ Management, $44(2), 137-151$.

Roodin, P., Brown, L. H., \& Shedlock, D. (2013). Intergenerational service-learning: A review of recent literature and directions for the future.Gerontology \& Geriatrics Education, 34(1), 3-25.

Scheier, M. F., \& Carver, C. S. (1985). Optimism, coping and health: Assessments and implications of generalized outcome expectancies. Health Psychology, 4, 219247. doi:10.1037//0278-6133.4.3.219 
Scholz, U., Doña, B. G., Sud, S., \& Schwarzer, R. (2002). Is general self-efficacy a universal construct? Psychometric findings from 25 countries.European Journal of Psychological Assessment, 18(3), 242.

Seligman, M. E. P. (1998). Learned optimism. New York, NY: Pocket Books.

Snyder, C. R. (2002). Hope theory: Rainbows in the mind. Psychological Inquiry, 13, 249-275.

Snyder, C. R., Irving, L., \& Anderson, J. (1991). Hope and health. In C. R. Snyder \& D. R. Forsyth (Eds.), Handbook of social and clinical psychology (pp. 285-305). Elmsford, NY: Pergamon.

Snyder, C. R., Rand, K. L., Sigmon, D. R. (2002). Hope theory: A member of the positive psychology family. In C. R. Snyder \& S. J. Lopez (Eds), Handbook of positive psychology, (pp. 257-276). New York, NY: Oxford University Press.

Snyder, C. R., Sympson, S., Ybasco, F., Borders, T., Babyak, M., \& Higgins, R. (1996). Development and validation of the state hope scale. Journal of Personality and Social Psychology, 70, 321-335.

Snyder, C. R., \& Taylor, J. D. (2000). Hope as a common factor across psychotherapy approaches: A lesson from the Dodo's Verdict. In C. R. Snyder (Ed.), Handbook on hope: Theory, measures, and applications (pp. 89-108). San Diego: Academic Press.

Stajkovic, A. D., Lee, D., \& Nyberg, A. J. (2009). Collective efficacy, group potency, and group performance: meta-analyses of their relationships, and test of a mediation model. Journal of Applied Psychology, 94(3), 814.

Stajkovic, A., \& Luthans, F. (1998). Self-efficacy and work-related performance: A meta-analysis. Psychological Bulletin, 124, 240-261.

Strage, A. A. (2000). Service-learning: Enhancing student learning outcomes in a college-level lecture course. Michigan Journal of Community Service Learning,7(1), 5-13.

Sutcliffe, K. M., \& Vogus, T. J. (2003). Organizing for resilience. In K. S. Cameron., J. E. Dutton, \& R. E. (Eds) Positive organizational scholarship.(pp. 94-110). San Francisco, CA: Berrett-Koehler.

Wagnild, G. M., \& Young, H. M. (1993). Development and psychometric evaluation of the resiliency scale. Journal of Nursing Management, 1, 165-178. 
Yorio, P., \& Ye, F. (2011). A meta-analysis on the effects of service-learning on the social, personal, and cognitive outcomes of learning. Academy of Management Learning \& Education, 11(1), 9-27.

Youssef, C. M., \& Luthans, F. (2007). Positive organizational behavior in the workplace: The impact of hope, optimism, and resilience. Journal of Management. 33(5), 774-800.

Zimmerman-Oster, K. \& Burkhardt, J.C. (1999). Leadership in the making: A comprehensive examination of the impact of leadership development programs on students. The Journal of Leadership Studies, 6, 50-66. 